\title{
Encephalocraniocutaneous lipomatosis with a mutation in the NF1 gene
}

\author{
E Legius, R Wu, M Eyssen, P Marynen, J P Fryns, J J Cassiman
}

\begin{abstract}
Encephalocraniocutaneous lipomatosis (ECCL) is a congenital hamartomatous disorder characterised by unilateral skin lesions, lipomas, and ipsilateral ophthalmological and cerebral malformations. The disorder is thought to represent a localised form of Proteus syndrome. In this report, a child is described with ECCL and a de novo nonsense mutation in exon 29 (S1745X) of the neurofibromatosis type 1 (NF1) gene. Although it is possible that both ECCL and NF1 occur coincidentally in this patient, we favour the hypothesis that in exceptional cases a mutation in the NF1 gene might give rise to severe congenital malformations such as ECCL. Possible pathogenetic mechanisms for these malformations are discussed.
\end{abstract}

(F Med Genet 1995;32:316-319)

Neurofibromatosis type 1 (NF1) is an autosomal dominant disorder characterised by café au lait spots, neurofibromas, Lisch nodules, axillary freckling, and learning disorders. ${ }^{1}$ The NF1 gene has been cloned and is localised on chromosome 17 (17q11.2)..$^{2-4}$ The gene has an open reading frame of 2818 amino acids. ${ }^{5} \mathrm{~A}$ central $1.2 \mathrm{~kb}$ region of the NF1 cDNA shows homology to the GTPase activating protein (GAP) family, and is involved in regulation of ras activity. ${ }^{6-8}$ The NF1 gene acts as a tumour suppressor gene ${ }^{9}$ and NF1 can be considered as a familial cancer syndrome. ${ }^{10}$ Several mutations in the NF1 gene have been described in different subjects with typical NF1 and in Watson syndrome patients, ${ }^{112}$ but not in patients with severe congenital malformations and NF1.

Encephalocraniocutaneous lipomatosis (ECCL) or Fishman syndrome is a neurocutaneous syndrome with unilateral lipomatous swellings over the cranium or face, ipsilateral lipodermoids of the sclera or cloudy cornea or both, ipsilateral brain malformations with calcifications and porencephalic cysts, mental retardation, and seizures. ${ }^{1314}$ ECCL is a sporadic disorder of unknown aetiology and shows considerable overlap with Proteus syndrome.

Proteus syndrome is a complex hamartomatous syndrome characterised by partial gigantism of the hands, feet, or limbs, plantar hyperplasia, haemangiomas, lipomas, lymphangiomas, verrucous epidermal naevi, macrocephaly, cranial hyperostoses, and long bone overgrowth. ${ }^{13}$ Every feature of ECCL can be seen in people with Proteus syndrome, and therefore several authors have suggested that ECCL is a more localised form of Proteus syndrome. ${ }^{15-18}$ Proteus syndrome is thought to result from somatic mosaicism, lethal in the non-mosaic state. ${ }^{1518}$ It was believed for some time that Joseph C Merrick (the "Elephant Man") was affected by NF1, and as a result of his popularity NF1 became known to the general public. Recently most experts agree that he suffered from Proteus syndrome, ${ }^{19}$ although there is still some uncertainty. ${ }^{20}$

In this report, we described a de novo nonsense mutation in the NF1 gene in an infant with ECCL. These results suggest that the spectrum of possible congenital malformations proven to be associated with mutations in the NF1 gene might include ECCL.

\section{Materials and methods}

PREPARATION OF DNA AND RNA

Peripheral blood lymphocytes of the proband were immortalised with Ebstein-Barr virus (EBV). Lymphoblastoid cells were used to extract DNA and RNA. DNA was extracted using standard procedures and total RNA was extracted using the RNAZOL B kit (Cinna/ Biotecx Texas, USA). In the parents, DNA was extracted from peripheral blood cells.

\section{SEQUENCING OF CDNA}

Total RNA $(1 \mu \mathrm{g})$ was reverse transcribed using $M-M L V$ reverse transcriptase (BRL) in a total volume of $20 \mu \mathrm{l}$. This cDNA was used to amplify the total coding region of the NF1 gene in eight different PCR experiments. Primers to amplify a $1334 \mathrm{bp}$ region containing the mutation were NF6A (sense primer 5'- CGA CAA CGT CTC CGC AGT CTA T - $3^{\prime}$ ) and NF6B (antisense primer 5'- GCG GAC CTG TGG CTA CTA AGA A $-3^{\prime}$ ). Primer NF6B was biotinylated at the $5^{\prime}$ end. PCR reactions consisted of $50 \mathrm{pmol}$ of each primer, 2.5 units Amplitaq (Cetus), $20 \mu$ l of reverse transcribed RNA. Buffer and nucleotides were adjusted to obtain the standard buffer and nucleotide concentration in $100 \mu \mathrm{l}$ as recommended by the manufacturer. Temperature cycling conditions were $94^{\circ} \mathrm{C}$ for three minutes followed by 40 cycles of $94^{\circ} \mathrm{C}$ for one minute, $58^{\circ} \mathrm{C}$ for one minute, and $72^{\circ} \mathrm{C}$ for three minutes. PCR product $(80 \mu \mathrm{l})$ was used to prepare single stranded DNA using Dynal-M280 beads as recommended by the manufacturer (Dynal, Oslo, Norway). The single stranded DNA was sequenced using the AutoRead sequencing kit (Pharmacia), with NF6S (5'- GTC TCC GCA 
GTC TAT ATC $-3^{\prime}$ ) as sequencing primer. The sequencing primer was conjugated with fluorescein isothiocyanate (FITC). Sequencing reactions were electrophoresed on an automated sequencer (ALF DNA sequencer, Pharmacia).

SEQUENCING OF GENOMIC DNA

Intronic PCR primers to amplify the $432 \mathrm{bp}$ genomic fragment containing exon 29 were: NF29A (sense primer 5'- GAG TTT AAT TCT CCA CTT C -3') and NF29B (antisense primer 5'- AGC AAC AAC CCC AAA TCA AAC $\left(-3^{\prime}\right)$. The antisense primer was biotinylated. Genomic DNA $(1 \mu \mathrm{g})$ was used to amplify exon 29 using $2.5 \mathrm{U}$ Amplitaq, $50 \mathrm{pmol}$ of each primer, and standard buffer and nucleotide concentrations as recommended by the manufacturer (Cetus). Temperature cycling conditions were $94^{\circ} \mathrm{C}$ for three minutes followed by 30 cycles of $94^{\circ} \mathrm{C}$ for 30 seconds, $52^{\circ} \mathrm{C}$ for 30 seconds, and $72^{\circ} \mathrm{C}$ for one minute. PCR product $(80 \mu \mathrm{l})$ was used to prepare single stranded DNA using Dynal-M280 beads (Dynal, Oslo, Norway). Single stranded DNA was sequenced using a sequencing primer conjugated with FITC (NF29S 5'- TTC TCC ACT TCA CCC CGT -3') as described for cDNA sequencing.

\section{Results}

\section{CLINICAL DATA}

The proband was a 2 year old boy, the only child of clinically healthy and non-consanguineous parents. At birth a large pigmented naevus on the left shoulder and on the left side of the neck, together with regions of alopecia on the left hemicranium, were noted. Convulsions were noted from the age of 3 months and proved to be difficult to control. Several café au lait spots $(>5)$ were also seen on the trunk and they became more prominent over the next months. At the age of 5 months several soft subcutaneous masses with the consistency of lipomata were noted in the left occipital region (fig 1). At that age motor development was moderately retarded and a right sided hemiplegia became evident. Because of progressive macrocrania and bilateral frontal subdural hygromas a subduroperitoneal drain was inserted at the age of 5 months. A CT scan of the brain showed hypotrophy of the left hemisphere with a dilated left ventricle and calcifications in the left occipital area (fig 2) progressing over time. A CT scan after contrast perfusion showed enhancement of the left occipital region suggesting the presence of a venous angioma, but no arteriography was performed. In addition to hypoplasia of the left hemisphere, nuclear magnetic resonance (NMR) scanning of the brain showed foci of enhanced T2 weighted signals bilaterally in the basal ganglia. The cornea of the left eye became cloudy at the age of 9 months and a corneal transplant was performed at the age of 23 months. Lisch nodules were not noted at that time. The left leg was $6 \mathrm{~mm}$ longer than the right leg, and a small $(1 \mathrm{~cm})$ soft swelling was noted on the

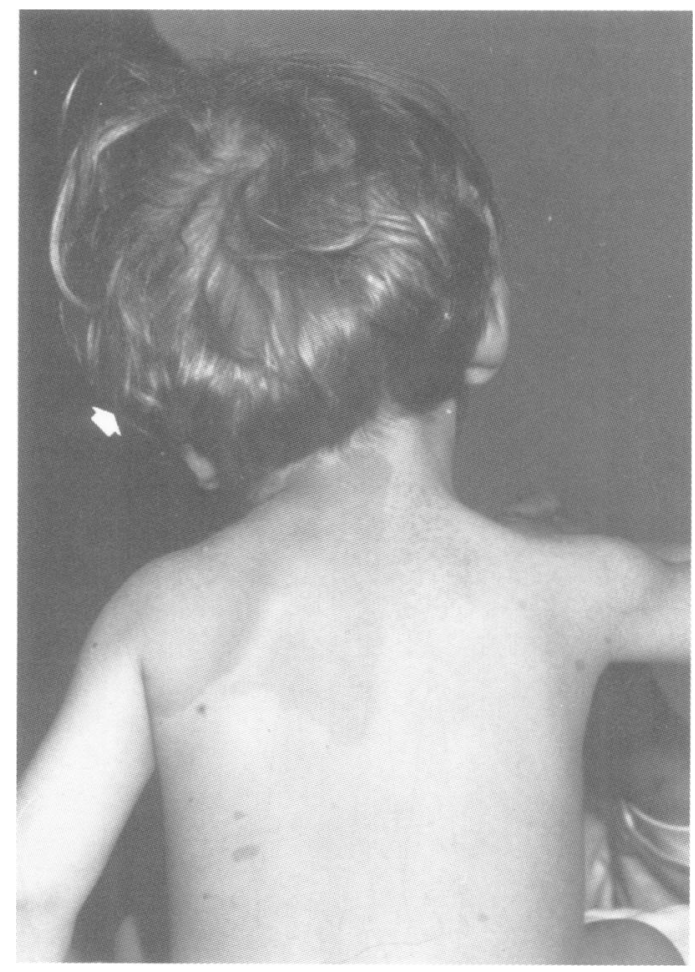

Figure 1 The proband showing the pigment naevus on the left shoulder and neck and café au lait spots on the back. Note the soft subcutaneous tumours on the left side of the head (arrow).

sole of the left foot. At the age of 2 years the sternal portion of the left clavicle progressively enlarged as a result of hyperostosis. This patient did not fulfil the diagnostic criteria for NF1, ${ }^{21}$ but showed all the signs of ECCL. ${ }^{17}$

Fibroblast cultures from two more patients, one with Delleman syndrome (oculocerebrocutaneous syndrome) and one with ECCL, were also available for study. Delleman syndrome also consists of unilateral eye abnormalities (orbital cysts) and ipsilateral skin and brain abnormalities.

MUTATIONAL ANALYSIS IN THE NF1 GENE DNA from the proband with ECCL was first

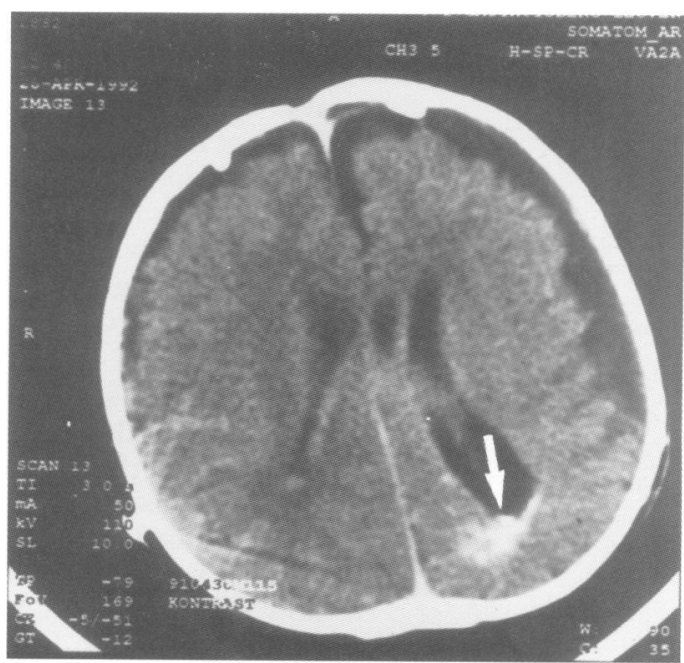

Figure $2 C T$ scan of the brain showing hypotrophy of the left cerebral hemisphere, a dilated left ventricle, and calcifications in the left occipital region (arrow). 

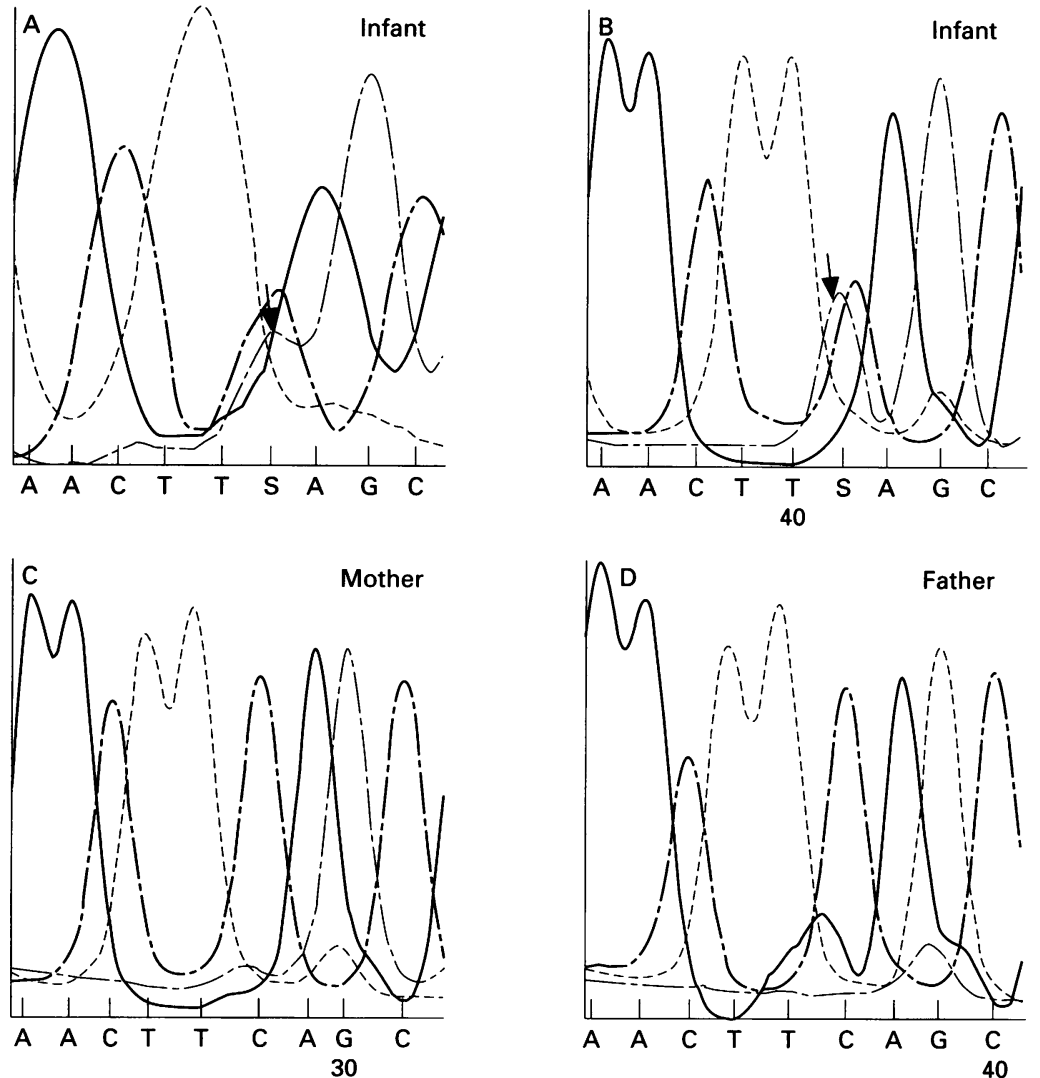

Figure 3 (A) Part of the sequence of the NF1 cDNA showing the $C$ to $G$ transversion at nucleotide position 5234 (arrow) together with the wild type sequence of the normal NF1 allele. The mutation changed the serine codon (TCA) at position 1745 to a stop codon (TGA). (B) Genomic sequence of exon 29 showing the same $C$ to $G$ transversion as in (A). The height of the $C$ is $49 \%$ (WT) of the following $C$ and the height of the $G$ is $42 \%(M)$ of the following $G$ (estimated signal ratio $W T / M=1 \cdot 16)$. This excludes significant mosaicism for the mutation. (C) Genomic sequence of relevant portion of exon 20 in the parents, showing only WT sequence.

screened for gross rearrangements in the NF1 gene. No abnormal Southern blot fragments were detected after $E c o$ RI and TaqI digestion using different portions of the NF1 cDNA as probes. $^{5}$ In addition, pulsed field gel electrophoresis showed only a normal NotI fragment using the same NF1 CDNA probes. EBV transformed lymphoblastoid cells from the proband were used to extract RNA and to prepare cDNA. The NF1 cDNA was amplified in eight overlapping fragments and each fragment was sequenced. A heterozygous mutation was identified which changed a $C$ at position 5234 of the NF1 cDNA into a G (fig $3 A$ ). This $\mathrm{C}$ to $\mathrm{G}$ transversion changed a serine at position 1745 to a stop codon (S1745X). The S1745X mutation was confirmed at the genomic level by sequencing exon 29 after amplification of this exon by PCR from white blood cell DNA (fig 3B).

White blood cell DNA from the parents was analysed for the same mutation in exon 29 as described in the proband and this showed only wild type exon 29 sequence (fig 3C).

Two further patients, one with Delleman syndrome (oculocerebrocutaneous syndrome) and one with ECCL, were analysed for the specific mutation in exon 29 of the NF1 gene found in the reported patient. Sequence analysis of exon 29 showed only wild type sequence.

\section{Discussion}

As described in this report, the clinical findings in the infant were identical to those reported in ECCL. Follow up examination showed features of NF1 such as café au lait spots and increased signal $\mathrm{T} 2$ weighted foci on a brain NMR scan, which are typically seen in NF $1 .^{22}$ In addition, molecular studies showed a de novo nonsense mutation in the NF1 gene. At present the child does not fulfil the diagnostic criteria for $\mathrm{NF} 1,{ }^{21}$ but this might change in a few years because several NF1 related findings are not present in young children. The coincidence of NF1 with ECCL is statistically unlikely, but not impossible. Fewer than 15 subjects with ECCL have been reported to date, ${ }^{23}$ and the incidence of new mutations in NF1 is 1 in 10000 , so the odds that both diseases should occur together coincidentally in the same person are very low. On the other hand ECCL and NF1 are two related neurocutaneous syndromes and both can have overgrowth as a symptom. Sometimes café au lait spots are reported in ECCL, ${ }^{24}$ together with larger areas of skin pigmentation as seen in NF1. Because of the above mentioned reasons, it is likely that the ECCL syndrome in the reported child is related to the de novo nonsense mutation in the NF1 gene. However, it is not clear at the moment how ECCL syndrome and NF1 are related to each other.

The infant in this report showed asymmetrical involvement of the brain with indications of a vascular abnormality (venous angioma). Fishman ${ }^{14}$ also reported progressive vascular abnormalities in a patient with ECCL and he suggested that the asymmetrical brain abnormality might result from circulatory impairment early in development with secondary involvement of the neuroectoderm. Vascular abnormalities are frequent in NF1, ${ }^{2526}$ and two differently spliced NF1 gene isoforms are expressed in blood vessels and are probably important for the regulation of growth of vascular smooth muscle. ${ }^{27} \mathrm{~A}$ vascular pathogenesis is one explanation for the observed congenital malformations in this patient. It is possible that as a result of the NF1 mutation the infant in this report suffered from an early embryonic vascular accident which disrupted the normal development of the left cerebral hemisphere. This may have resulted in an ECCL malformation pattern at birth.

Recently Rizzo et $a l^{15}$ and Cohen ${ }^{18}$ suggested that somatic mosaicism could explain the localised abnormalities observed in ECCL. In the present patient we found no evidence for somatic mosaicism for an NF1 gene mutation: analysis of the NF1 mutation did not show mosaicism in white blood cells, café au lait spots were randomly distributed over the body, and increased T2 weighted signals were seen bilaterally in the basal ganglia. However, another valid hypothesis to explain the ECCL syndrome as a result of an NF1 mutation is somatic mosaicism for an additional second mutation, either in another unrelated gene or in the normal NF1 allele. The latter would then result in a heterozygous state for an NF1 mutation in most cells and in a homozygous 
state for a defect in the NF1 gene in cells from the left hemicranium. This could explain the severe and localised lesions observed in the patient in this report. However, there was no tissue available to study this last interesting hypothesis concerning the pathogenesis of the congenital malformations. As a last hypothesis we have to mention the possibility that some of the malformations in this child are the result of non-genetic events acting during early embryonic development.

The data in this report suggest that, at least in some patients, the ECCL phenotype might be the result of a mutation in the NF1 gene alone or in combination with another genetic or non-genetic event, whereas in other subjects with ECCL the aetiology might be different.

This observation shows the importance of studying the involvement of the NF1 gene in patients with atypical NF1 and related syndromes. However, we do not think that the S1745X mutation is specific for ECCL because two other patients with a very similar condition showed a normal sequence for exon 29 of the NF1 gene. It is, of course, still possible that these two patients show mutations in other parts of the NF1 gene, not yet analysed. Moreover there is a general lack of genotype to phenotype correlation in NF $1,{ }^{11}$ and the same mutation might result in a completely different phenotype in different members of the same family. ${ }^{28}$ Another example of lack of genotype to phenotype correlation is Watson syndrome, a variant of NF1, in which a large deletion in the NF1 gene ${ }^{29}$ as well as a 42 bp duplication in the NF1 gene have been described. ${ }^{30}$

The present observation expands the spectrum of clinical abnormalities resulting from NF1 mutations.

The authors thank R Hennekam for the fibroblast cultures of the second patient with ECCL and the patient with Delleman syndrome and John Carey for helpful discussion on the clinical aspect of the patient.

1 Riccardi VM, Eichner JE. Neurofibromatosis: phenotype, natural history and pathogenesis. Baltimore: The Johns Hopkins University Press, 1988

2 Cawthon RM, Weiss R, Xu GF, et al. A major segment of the neurofibromatosis type 1 gene: cDNA sequence, genomic structure, and point mutations. Cell 1990;62: 193-201.

3 Viskochil D, Buchberg AM, Xu G, et al. Deletions and a translocation interrupt a cloned gene at the neurofibromatosis type 1 locus. Cell 1990;62:187-92.

4 Wallace MR, Marchuk DA, Andersen LB, et al. Type 1 neurofibromatosis gene: identification of a large transcript disrupted in three NF1 patients. Science 1990;249:181-6.
5 Marchuk DA, Saulino AM, Tavakkol R, et al. cDNA cloning of the type 1 neurofibromatosis gene: complete sequence of the NF1 gene product. Genomics 1991;11:931-40.

$6 \mathrm{Xu} \mathrm{G}$, Lin B, Tanaka K, et al. The catalytic domain of the neurofibromatosis type 1 gene product stimulates ras GTPase and complements ira mutants of S. cerevisiae. Cell 1990;63:835-41.

7 Martin GA, Viskochil D, Bollag G, et al. The GAP-related domain of the neurofibromatosis type 1 gene product interacts with ras p21. Cell 1990;63:843-9.

8 Ballester R, Marchuk D, Boguski M, et al. The NF1 locus encodes a protein functionally related to mammalian GAP and yeast IRA proteins. Cell 1990;63:851-9.

9 Legius E, Marchuk DA, Collins FS, Glover TW. Somatic deletion of the neurofibromatosis type 1 gene in a neurofibrosarcoma supports a tumour suppressor gene hypothesis. Nature Genet 1993;3:122-6.

10 Knudson AJ. Genetics of human cancer. Annu Rev Genet 1986;20:231-51.

11 Upadhyaya $\mathrm{M}$, Shen $\mathrm{M}$, Cherryson A, et al. Analysis of Upadhyaya $\mathrm{M}$, Shen $\mathrm{M}$, Cherryson $\mathrm{A}$, et al. Analysis of
mutations at the neurofibromatosis 1 (NF1) locus. Hum mutations at the neurofibrom
Mol Genet 1992;1:735-40.

12 Tassabehji M, Strachan T, Sharland M, et al. Tandem duplication within a neurofibromatosis type I (NF1) gene exon in a family with features of Watson syndrome and Noonan syndrome. Am F Hum Genet 1993;53:90-5.

13 Haberland C, Perou M. Encephalocraniocutaneous lipomatosis. Arch Neurol 1970;22:144-55.

14 Fishman MA. Encephalocraniocutaneous lipomatosis. $\mathcal{F}$ Child Neurol 1987;2:186-93.

15 Rizzo R, Pavone L, Micali G, Nigro F, Cohen MM Jr. Encephalocraniocutaneous lipomatosis, Proteus syn-
drome, and somatic mosaicism. Am $\mathcal{f}$ Med Genet 1993; 47:653-5.

16 Wiedemann HR, Burgio GR. Encephalocraniocutaneous lipomatosis and Proteus syndrome. Am $\mathcal{F}$ Med Genet 1986; 25:403-4.

17 McCall S, Ramzy MI, Cure JK, Pal GS. Encephalocraniocutaneous lipomatosis and the Proteus syndrome. Am f Med Genet 1992;43:662-8.

18 drome. Am F Med Genet 1992;43:662-8. somatic mosaicism and selective review. Am $\mathcal{f}$ Med Genet somatic mosaicism

19 Cohen MM Jr. Understanding Proteus syndrome, unmasking the elephant man, and stemming elephant fever. Neurofibromatosis 1988;1:260-80.

20 Hotamisligil GS. Proteus syndrome and neurofibromatosis. Neurofibromatosis 1989;2:339-40.

21 Anonymous. National Institutes of Health Consensus Development Conference Statement: neurofibromatosis. Bethesda, Md, USA 13-15 July, 1987. Neurofibromatosis 1988;1:172-8.

22 DiMario FJ Jr, Ramsby G, Greenstein R, Langshur S, Dunham B. Neurofibromatosis type 1: magnetic resonance imaging findings. 7 Child Neurol 1993;8:32-9.

23 Grimalt R, Ermacora E, Mistura L, et al. Encephalocraniocutaneous lipomatosis: case report and re-

24 Al-Mefty O, Fox JL, Sakati N, Bashir R, Probst F. The multiple manifestations of the encephalocraniocutaneous multiple manifestations of the encephalocraniocutaneo
lipomatosis syndrome. Childs Nerv Syst 1987;3:132-4.

25 Riccardi VM. Type 1 neurofibromatosis and the pediatric patient. Curr Probl Pediatr 1992;22:66-106.

26 Greene JFJ, Fitzwater JE, Burgess JH. Arterial lesions associated with neurofibromatosis. Am $\mathcal{F}$ Clin Pathol 1974; 62:481-7.

27 Ahlgren-Beckendorf JA, Maggio WW, Chen F, Kent TA. Neurofibromatosis $1 \mathrm{mRNA}$ expression in blood vessels. Biochem Biophys Res Commun 1993;197:1019-24.

28 Riccardi VM. Genotype, malleotype, phenotype, and randomness: lessons from neurofibromatosis-1 (NF1). $A m \mathcal{F}$ Hum Genet 1993;53:301-4.

29 Upadhyaya $M$, Shen $M$, Cherryson A, et al. Analysis of mutations at the neurofibromatosis 1 (NF1) locus. Hum Mol Genet 1992;1:735-40.

30 Tassabehji M, Strachan T, Sharland M, et al. Tandem duplication within a neurofibromatosis type I (NF1) gene exon in a family with features of Watson syndrome and Noonan syndrome. Am ₹ Hum Genet 1993;53:90-5. 